\title{
Groundwater arsenic contamination from parts of the Ghaghara Basin, India: influence of fluvial geomorphology and Quaternary morphostratigraphy
}

\author{
Babar Ali Shah ${ }^{1}$
}

Received: 13 June 2015/Accepted: 31 August 2016/Published online: 13 September 2016

(c) The Author(s) 2016. This article is published with open access at Springerlink.com

\begin{abstract}
A groundwater arsenic (As) distribution in Faizabad, Gonda, and Basti districts of Uttar Pradesh is shown in the entrenched channels and floodplains of the Ghaghara River. Tubewell water samples were analysed for As through flow injection hydride generation atomic absorption spectrometry (FI-HG-AAS) system. About 38, 61, and $42 \%$ of tubewells in Faizabad, Gonda, and Basti districts, respectively, have As $>10 \mu \mathrm{g} / \mathrm{l}$ (WHO guideline). Moreover, 15, 45, and $26 \%$ of tubewells in Faizabad, Gonda, and Basti districts, respectively, have As above $50 \mu \mathrm{g} / \mathrm{l}$. About 86, 69, and $35 \%$ of tubewells in Faizabad, Gonda, and Basti districts, respectively, are from shallow depth (21-45 m), and it is worth noticing that $47 \%$ Ascontaminated (As $>10 \mu \mathrm{g} / \mathrm{l}$ ) tubewells in these three districts are located within the depth of 10-35 $\mathrm{m}$ in Holocene Newer Alluvium aquifers. The high content of As $(7.11 \mathrm{mg} / \mathrm{kg})$ is measured in suspended river sediments of the Ghaghara River. Most of the As-contaminated villages in the Ghaghara Basin are located close to abandoned or present meander channels and floodplains of the Ghaghara River. In contrast, tubewells in Faizabad, Ayodhya, and Nawabganj towns are As-safe because of their positions on the Pleistocene Older Alluvium upland surfaces. Quaternary geomorphology plays an important role in groundwater arsenic contamination in the Ghaghara Basin. The sources of groundwater arsenic are geogenic and perennial mountainous rivers in the Ghaghara Basin supplied high sediment loads. The arsenic in groundwater of Ghaghara Basin is getting released from associated sediments which
\end{abstract}

Babar Ali Shah

bashahju@yahoo.com

1 Department of Geological Sciences, Jadavpur University, Kolkata 700032, India were likely deposited from the Himalayas. The process of release of groundwater arsenic is reductive dissolution of iron hydroxides.

Keywords Groundwater arsenic · Ghaghara Basin · Older alluvium · Holocene aquifer - Geomorphology

\section{Introduction}

Arsenic (As) is found in soil and groundwater by natural and anthropogenic sources. High concentrations of As is one of the most hazardous chemical elements in drinking water in several parts of the world. Millions of tubewells in the Ganges-Brahmaputra-Meghna (GBM) delta plain are As-contaminated in the groundwater (Ravenscroft et al. 2009). Although the major switch from polluted surface water to groundwater in early 1970s helped people to avoid waterborne diseases, but naturally occurring high concentration of dissolved As in groundwater of alluvial aquifers has been causing serious health problems in millions of people for the last three decades. The upper permissible limit of As in drinking water is $10 \mu \mathrm{g} / \mathrm{l}$ in WHO guideline (WHO 1993) which has been endorsed by Bureau of Indian Standards (BIS 2003). The mode of occurrence, origin, and mobility of As in sedimentary aquifers in the Bengal Delta and other fluvial-deltaic setting in different parts of the world are mainly influenced by local geology, geomorphology, hydrogeology, and geochemistry of sediments and water, as well as anthropogenic activities (Nickson et al. 1998; Acharyya et al. 2000; Kinnibugh and Smedley 2001). The worst As-affected regions in Asia are mainly Bangladesh and West Bengal in India (Dhar et al. 1997; Nickson et al. 1998; Acharyya et al. 2000; Kinnibugh and Smedley 2001; Acharyya and Shah 2007, 2010; von 
Brömssen et al. 2007; Ravenscroft et al. 2009; Shamsudduha et al. 2008). Arsenic pollution in groundwater is also reported from South, West and East Asia viz., Pakistan, People Republic of China, Taiwan, Vietnam, Laos and Cambodia, Nepal, Egypt and Yemen (Tseng et al. 2000; Berg et al. 2001; Mondal and Suzuki 2002; Nickson et al. 2005; Gurung et al. 2005; Al-Mikhlafi 2010; Kashouty et al. 2012).

Recently, groundwater As contamination has been reported from the Middle Ganga Plain in the states of Jharkhand, Bihar, and Uttar Pradesh (Chakraborty et al. 2003; Bhattacharjee et al. 2005; Shah 2008). The Ghaghara River is a distributary of the River Ganges and is a significant river in UP with many cities, towns and villages are located on its bank (Fig. 1). This study is undertaken for groundwater As distribution in Faizabad, Gonda, and Basti districts of Uttar Pradesh involving tubewells within Holocene Newer Alluvium aquifers, as well as, Pleistocene Older Alluvium aquifers. The main objective of the study is to investigate the distribution of groundwater As in entrenched channels and floodplains of the Ghaghara River under Quaternary geomorphological setting (Fig. 2).

\section{Study area}

The Ghaghara River has originated from Matsatung glacier in the Himalayas near Mansarovar Lake in Tibet and traveled a distance of about $1080 \mathrm{~km}$ in NW-SE direction, to join the Ganga River. The Ghaghara River adopts a meandering path through the alluvial plains, frequently shifting their courses and forming ox-bow lakes. The topography of the area is heterogeneous; varying between upland surfaces, plain areas and low-lying small natural bodies, viz., swamp and ponds. The Older Alluvium is located at an elevation of $10-20 \mathrm{~m}$ above the river level and constitutes the higher interfluve areas. The Pleistocene Older Alluvium surfaces in the Ghaghara Basin are characterized by yellow-brown coloured sediments with profuse calcareous and ferruginous concretions (Fig. 3). Newer Alluvium forms the river valley terrace and is located at an elevation of 5-10 $\mathrm{m}$ above river level. The Holocene Newer Alluvium surfaces are recognized by grey to black coloured organic-rich argillaceous sediments in entrenched channels and floodplains of the Ghaghara River (Fig. 3). The area is under humid subtropical climate and the annual average rainfall is $1041 \mathrm{~mm}$. Temperature ranges between maximum $\left(47^{\circ} \mathrm{C}\right)$ in summer and minimum $\left(2{ }^{\circ} \mathrm{C}\right)$ in winter.

The distribution of groundwater As in the Ghaghara Basin is prepared based on the Survey of India topographic sheets $(63 \mathrm{~J} / 1, \mathrm{~J} / 2, \mathrm{~J} / 5$, and $\mathrm{J} / 6)$ in 1:50,000 scale, with field checks to identify fluvial landforms and soil characters. The study areas in Faizabad, Gonda, and Basti districts along entrenched channels and floodplains of the Ghaghara River are shown in Fig. 2. In this study, approximately $1500 \mathrm{~km}^{2}$ areas have been mapped to delineate groundwater As-contaminated and As-safe areas.
Fig. 1 Quaternary sediments in the Indo-Ganga Basin and Bengal Basin. The study area in the Ghaghara Basin is shown in Fig. 2. A Allahabad, $V$ Varanasi, $B X$ Buxar, $B$ Ballia, $C$ Chappra, $P$ Patna, $B G$ Bhagalpur

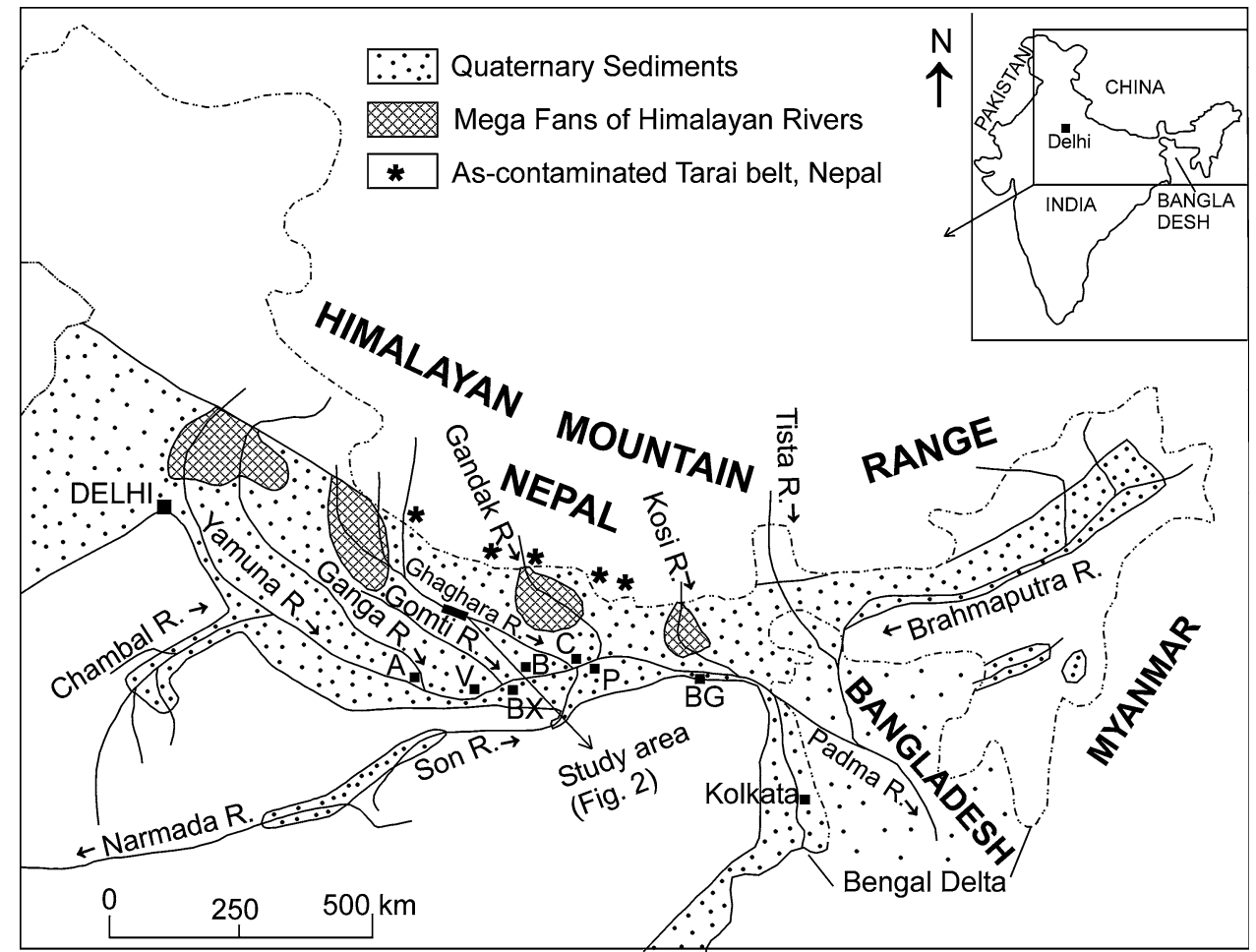


Fig. 2 Groundwater arsenic distribution in Faizabad, Gonda, and Basti districts of Uttar Pradesh

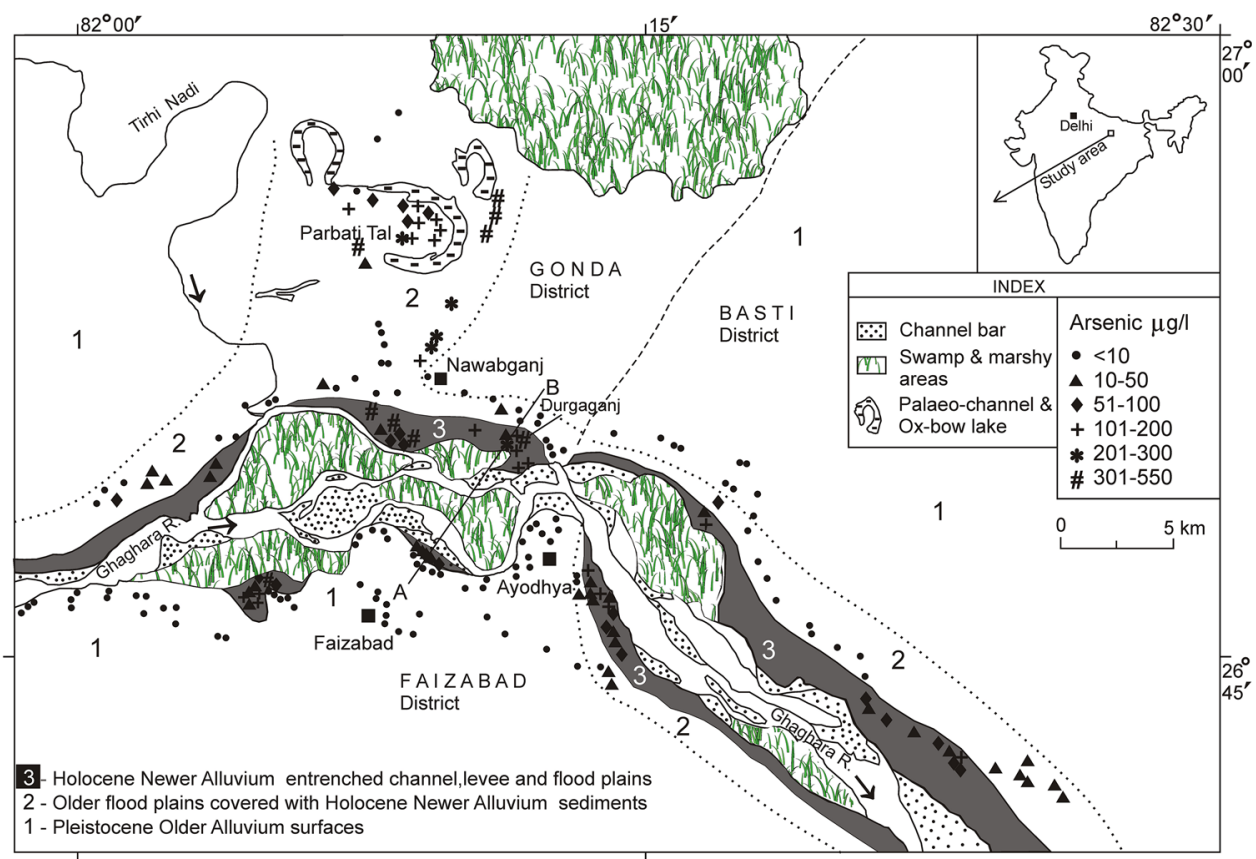

Pleistocene to Recent) in order of superposition. The Siwalik Supergroup is further subdivided into Lower, Middle, and Upper groups ranging in age from Middle Miocene to Early Pleistocene in northern part of the Siwalik Basin forming the Outer Himalaya. The Banda Group in the southern part of the basin corresponds to the Upper Siwalik (Kumar et al. 1996).

The sediments formed Bandra Older Alluvium which is characterized by variegated clays followed by the clastic sediments. However, the sediments derived from the Himalayas in northern part of the basin constitute the Upper Siwalik (Dwivedi et al. 1997).

The Ghaghara Valley in the Ganga Plain consists of thick pile of Quaternary sediments. Geomorphologically, the Older Alluvium surfaces, i.e. the Varanasi Older Alluvium constitute upland surfaces which are also recognized as the Bhangar surface and are occupying a major part of the area. The Varanasi Older Alluvium consists dominantly of multiple fill polycyclic sequence of sand, silt, and clay (Kumar et al. 1996). In the Ghaghara Basin, the top $3 \mathrm{~m}$ part is of silt-clay facies corresponding to suspension load of floodplain environment underlain by arenaceous facies corresponding to channel fill palaeoenvironment. The subsurface boreholes down to a depth of $300 \mathrm{~m}$ record a number of calcrete (kankar) and argillaceous bands at various levels (Dwivedi et al. 1997).

The river Ghaghara draining the area has developed a second geomorphic unit, the low-lying floodplains-the Khadar surface of the river. The main geomorphic features are giant channel bar, natural levee, and floodplains. The Holocene Newer Alluvium comprises grey to black Upper Pleistocene), and Newer Alluvium (Upper been subdivided the sediments into Older Alluvium and Newer Alluvium (Pascoe 1964). This classification was revised by Pathak et al. (1978) as Upper Siwalik (Upper Pliocene to Lower Pleistocene), Older Alluvium (Middle to

Fig. 3 Pleistocene Older Alluvium sediments (a) with calcareous and ferruginous concretion $(k)$ in Faizabad areas. Entrenched channels and
floodplains of the Ghaghara River (b)

\section{Geological setting}

The Quaternary geology of the Indo-Gangetic plains has
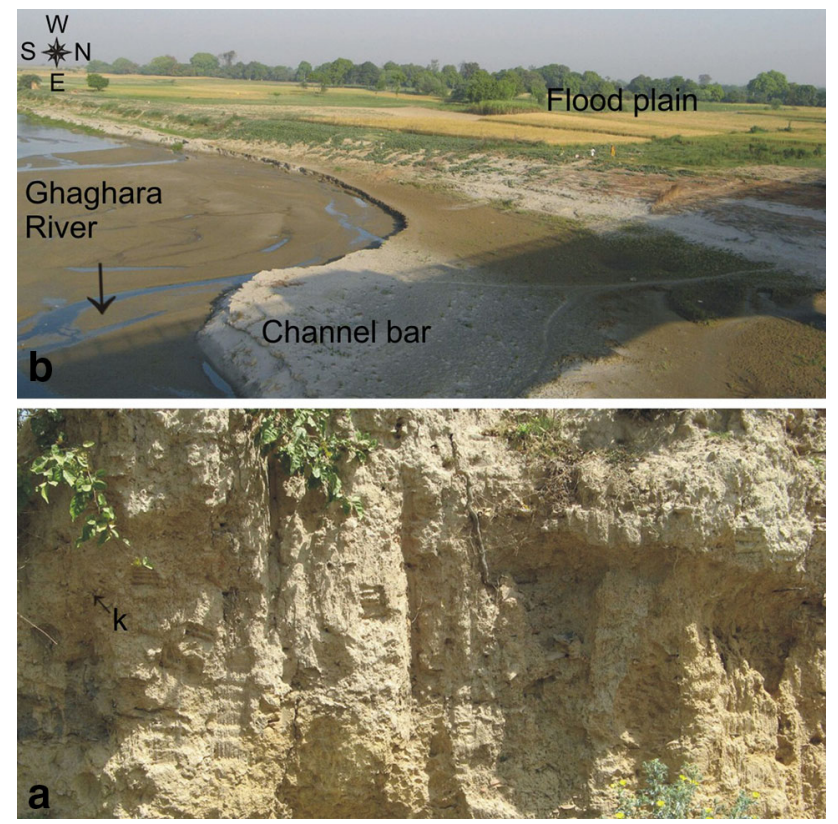
coloured organic-rich argillaceous sediments in entrenched channels and floodplains of the Ghaghara River. The top thin layer of silt-clay has been deposited in a lacustrine condition towards the close of sedimentation. The landscape of the study area is typically fluvial, characterized mainly by active channels, abandoned channels, natural levees, back swamps, and floodplains. The Quaternary lithostratigraphy in the Ghaghara Basin has been classified broadly into two units, i.e. Older Alluvium and Newer Alluvium (Table 1).

The subsurface aquifer system in the area is known from the study of Central Ground Water Board (CGWB) exploratory well data. Groundwater occurs in pore spaces of the unconsolidated alluvial sediment in the zone of saturation. The groundwater in the area occurs both under confined and water table conditions. The area is underlain by the pile of unconsolidated Quaternary alluvium consisting of clays, silt, occasional calcrete (kankar), sand of various grades, and gravels in different proportions. The pre-monsoon depth to water level ranges from 2.46 to $6.48 \mathrm{mbgl}$, whereas in post-monsoon depth to water level varies from 1.12 to $5.6 \mathrm{mbgl}$. Sediment from ground level varies from 15 to $20 \mathrm{~m}$, comprises fine to medium grained sand with thin clay at top. Water level varies from 2.45 to $7.80 \mathrm{mbgl}$ and the depth of dug wells varies from 3.60 to $12.50 \mathrm{mbgl}$ (Srivastava 2009).

\section{Materials and methods}

About 80 tubewell water samples were tested on spot through EZ As Test Kit, Hach, USA (Cat No. 28228-00) in Faizabad, Gonda, and Basti districts of Uttar Pradesh. The minimum determination limit of Kit is $10 \mu \mathrm{g} / \mathrm{l}$. Kit data was used as a guide to delineate As-contaminated and Assafe areas in the field. In this study, 231 tubewell water samples from the above districts were tested in the laboratory.

The geographic location of each tubewell was recorded by a global positioning system (Garmin eTrex Vista), and the depth of the tubewell was acquired through personal communication with tubewell owners. The results of As concentrations in tubewells is shown in Table 2, and the GPS location of each tubewell is marked in the toposheet to prepare As distribution map in entrenched channels and floodplains of the Ghaghara River (Fig. 2).

Hand tubewell water samples were collected in acid prewashed $10 \mathrm{ml}$ plastic bottles. Immediately after collection, one drop of dilute nitric acid (1:1) GR Grade was added as preservative. All reagents were of Analar grade. A solution of $2 \% \mathrm{NaBH}_{4}$ (Merck, Schuchardt, Germany) was prepared in $0.5 \% \mathrm{NaOH}$ (Merck, Bombay, India). A 5.0 M solution of $\mathrm{HCl}$ (Merck, Bombay, India) was used. All these solutions were prepared using distilled de-ionised water. The flow rate for both tetrahydroborate and hydrochloride acid was $1 \mathrm{ml} / \mathrm{min}$. Blank was prepared and measured under the same conditions. The tubewell water samples were analysed for As following a flow injection hydride generation atomic absorption spectrometry (FIHG-AAS) system. Model Analyst-700 spectrometer with As lamp (lamp current $380 \mathrm{~mA}$ ), illuminating at $193.7 \AA$ (specific for As) was utilized for this purpose (Biswas et al. 2008).

Four sediment core samples from the borehole in Durgaganj Village $\left(26^{\circ} 49.128^{\prime}: 82^{\circ} 11.834^{\prime}\right)$ were collected through hand-flapper boring. One sediment sample of

Table 1 Lithostratigraphy and morphostratigraphy in the Ghaghara Basin, Uttar Pradesh

\begin{tabular}{|c|c|c|c|c|}
\hline \multirow[t]{2}{*}{ Age } & \multicolumn{2}{|l|}{ Lithostratigraphy } & \multicolumn{2}{|l|}{ Morphostratigraphy } \\
\hline & Lithounits & Lithology & Morphounits & Landform \\
\hline \multicolumn{5}{|l|}{ Holocene } \\
\hline Newer & Recent Alluvium & $\begin{array}{l}\text { Grey, fine, micaceous sand and silt } \\
\quad(4-8 \mathrm{~m})\end{array}$ & $\begin{array}{l}\text { i. Swamps } \\
\text { ii. Flood plain (Khadar } \\
\text { surface) }\end{array}$ & $\begin{array}{l}\text { Abandoned channels/ } \\
\text { lakes }\end{array}$ \\
\hline Alluvium & $\begin{array}{l}\text { Ghaghara } \\
\text { Terrace } \\
\text { Alluvium }\end{array}$ & $\begin{array}{l}\text { Top clay, grey fine to medium } \\
\text { grained micaceous sand and } \\
\text { sandy silt }(9-20 \mathrm{~m})\end{array}$ & $\begin{array}{l}\text { i. Ghaghara older flood } \\
\text { plains } \\
\text { ii. Ghaghara erosional } \\
\text { terrace }\end{array}$ & $\begin{array}{l}\text { Point and channel bars, } \\
\text { meander cut-offs } \\
\text { abandoned channels }\end{array}$ \\
\hline \multicolumn{5}{|l|}{ Disconformity } \\
\hline Mid to Late Pleistocene & $\begin{array}{l}\text { Varanasi Older } \\
\text { Alluvium }\end{array}$ & $\begin{array}{l}\text { Polycyclic sequence of brownish } \\
\text { yellow oxidized sand, silt and } \\
\text { clay with calcrete (kankar). } \\
\text { Argillaceous facies dominates in } \\
\text { the upper part and arenaceous in } \\
\text { the lower part }(+300 \mathrm{~m})\end{array}$ & $\begin{array}{l}\text { Varanasi Older } \\
\text { Alluvium plain } \\
\text { (Bhangar surface) }\end{array}$ & Palaeochannels \\
\hline
\end{tabular}

Pre-Quaternary concealed basement rocks 
Table 2 Tubewell As $(\mu \mathrm{g} / \mathrm{l})$ distribution in percentage in the Ghaghara Basin, Uttar Pradesh

\begin{tabular}{lllcccc}
\hline Study area & $>10$ & $>50$ & $>100$ & $>200$ & $>300$ & Max. As \\
\hline Faizabad district $(N=101)$ & 38 & 15 & 9 & 5 & 2 & 350 \\
Gonda district $(N=88)$ & 61 & 45 & 33 & 25 & 18 & 510 \\
Basti district $(N=42)$ & 42 & 26 & - & - & 150 \\
\hline
\end{tabular}

approximately $20 \mathrm{~g}$ clayey sand from the depth of $23 \mathrm{~m}$ was taken in this study and the sample was dried in an oven at about $50{ }^{\circ} \mathrm{C}$ for approximately $24 \mathrm{~h}$. Sediment sample was ground homogenously and crushed with a mortar and pestle. Sample weighing $0.5 \mathrm{~g}$ was taken in Teflon bomb, and $2 \mathrm{ml}$ nitric acid was added with it. It was digested at $120{ }^{\circ} \mathrm{C}$ temperature for $8 \mathrm{~h}$ in hot air oven. Subsequently, vessel was emptied in a beaker and the sample evaporated near to dryness. The $5 \mathrm{ml}$ distilled de-ionised water was added to the digested sample, and it was filtered through $0.45 \mu$ Millipore filter. During analysis $5 \mathrm{ml}$ acidified sample was added with $10 \mathrm{ml}$ buffer, $5 \mathrm{ml}$ hydroxylamine hydrochloride, and $2.5 \mathrm{ml}$ phenanthroline, and a final volume of $25 \mathrm{ml}$ was prepared. The prepared solution was used for As and iron analysis. Iron was analysed by 1,10phenanthroline method by the use of UV spectrophotometer.

The accuracy of analytical method using FI-HG-AAS was verified by analysing standard reference sample of water (quality control sample for trace metal analysis) (certified value $17.6 \pm 2.21 \mu \mathrm{g} / \mathrm{l}$ ) from the US Environmental Protection Agency, Environmental monitoring and support laboratory, Cincinnati, Ohio, USA and certified reference material BND 301 (certified value $990 \pm 200 \mu \mathrm{g} / \mathrm{l}$ ), from the National Physical Laboratory, New Delhi, India.

\section{Results}

Arsenic contamination in tubewell water in Faizabad, Gonda, and Basti districts along the Ghaghara River have been observed in significant amount. About $38 \%$ of tubewells in Faizabad district, $61 \%$ of tubewells in Gonda district, and $42 \%$ of tubewells in Basti district have As $>10 \mu \mathrm{g} / \mathrm{l}$ (WHO guideline). Moreover, $15 \%$ of tubewells in Faizabad district, $45 \%$ of tubewells in Gonda district, and $26 \%$ of tubewells in Basti district have As above $50 \mu \mathrm{g} / \mathrm{l}$ (Table 2).

Maximum concentrations of As in tubewells from Faizabad, Gonda, and Basti districts are 350, 510, and $150 \mu \mathrm{g} / \mathrm{l}$, respectively. The density of As-contaminated tubewells in Gonda districts is higher compared to that of the Faizabad and Basti districts, and even $25 \%$ of tubewells in Gonda district reveal occurrence of As above $200 \mu \mathrm{g} / \mathrm{l}$ (Table 2). Groundwater As distributions in entrenched channels and floodplains of the Ghaghara River are divided into three parts viz., (1) Pleistocene Older Alluvial uplands surfaces, i.e. Varanasi Older Alluvium with oxidized to yellow-brown coloured sediments, and aquifers are As-safe in groundwater, (2) narrow belts of older floodplains covered with Holocene sediments on top, and aquifers are locally As-contaminated, and (3) Holocene to recent entrenched channels and floodplains of the Ghaghara River and tubewells are highly As-contaminated in groundwater (Fig. 2). Maximum level of As in tubewell is $510 \mu \mathrm{g} / \mathrm{l}$ from Bakir Mahangopur Village $\left(26^{\circ} 51.559^{\prime}: 82^{\circ} 47.669^{\prime}\right)$ of Nawabganj block.

The subsurface information of tubewell has been collected from owners of the tubewells as well as from the local drillers and accordingly a profile section (A-B) is plotted (Fig. 4). The profile section shows that tubewells located in Holocene Newer Alluvium aquifers in the Faizabad side have As concentrations of 25,23 , and $72 \mu \mathrm{g} /$ 1 corresponding to the depth of 30,37 , and $12 \mathrm{~m}$, respectively. Moreover, tubewells located in Holocene Newer Alluvium aquifers in the Durgaganj areas have As concentrations of 140,125 , and $410 \mu \mathrm{g} / \mathrm{l}$ corresponding to the depth of 33, 33, and $10 \mathrm{~m}$, respectively. However, As-safe tubewells $(<10 \mu \mathrm{g} / \mathrm{l})$ are mainly located in the Pleistocene Older Alluvium aquifers at the both end of Faizabad and Durgaganj areas (Fig. 4). Tubewells in Faizabad town is virtually free of As contamination $(<10 \mu \mathrm{g} / \mathrm{l})$ in

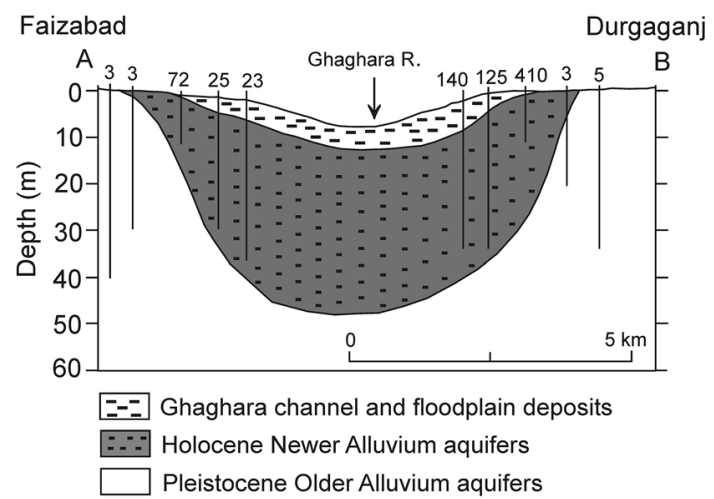

Fig. $4 A-B$ profile section is marked in Fig. 2. Arsenic value $(\mu \mathrm{g} / \mathrm{l})$ of each tubewell is marked its top 
groundwater, as it is located on the Pleistocene Older Alluvium surfaces (Fig. 2).

Arsenic-contaminated areas in and around of Faizabad, Ayodhya, and Nawabganj towns are mainly confined in the meandering belt of the Ghaghara River. Durgaganj Village $\left(26^{\circ} 49.786^{\prime}: 82^{\circ} 11.873^{\prime}\right)$ and Jayedpur Majha $\left(26^{\circ} 49.786^{\prime}: 82^{\circ} 11.873^{\prime}\right)$ are located on the north bank of Ghaghara River where As concentrations in tubewells are 410 and $455 \mu \mathrm{g} / \mathrm{l}$, respectively. These areas are in channels and flood plains of the Ghaghara River. However, opposite side of Durgaganj Village is Ayodhya town, and tubewells in Ayodhya town are As-safe in groundwater $(<10 \mu \mathrm{g} / \mathrm{l})$ because of their positions on Older Alluvium upland surfaces (Fig. 2). As-contaminated tubewells are also located on the older floodplains (zone 2) to the south-east of Ayodhya town near the bank of Ghaghara River. These areas are under shallow cover of Newer Alluvium Holocene sediments with As level $\leq 200 \mu \mathrm{g} / \mathrm{l}$. It may be noted that villages around Parbati Tal are As-affected in groundwater. These inundated areas consist of palaeochannels and ox-bow lakes of the Ghaghara River and its tributaries. Raghuraj Nagar Village $\left(26^{\circ} 56.101^{\prime}: 82^{\circ} 10.969^{\prime}\right)$, although located in this area, shows maximum As concentration of $450 \mu \mathrm{g} / \mathrm{l}$ (Fig. 2).

Faizabad and Ayodhya twin towns are historically famous places, and the disputed land of Babri Masjid and Ram Mandir issue has evoked international attention. The twin towns, on the southern bank of the Ghaghara River, are located on the yellow-brown coloured oxidized Pleistocene Older Alluvium upland surfaces with calcareous and ferruginous concretions (Fig. 5). Tubewells in twin towns are As-safe in groundwater. However, tubewells in outskirts of Faizabad town near Pathan Toli $\left(26^{\circ} 47.136^{\prime}: 82^{\circ} 09.990^{\prime}\right)$ and Kala Majha $\left(26^{\circ} 46.999^{\prime}: 82^{\circ} 04.627^{\prime}\right)$ have maximum As concentrations of 72 and $350 \mu \mathrm{g} / \mathrm{l}$, respectively. About $47 \%$ As-contaminated (As $>10 \mu \mathrm{g} / \mathrm{l})$ tubewells in these three districts are located within the depth of 10-35 m (Fig. 6).

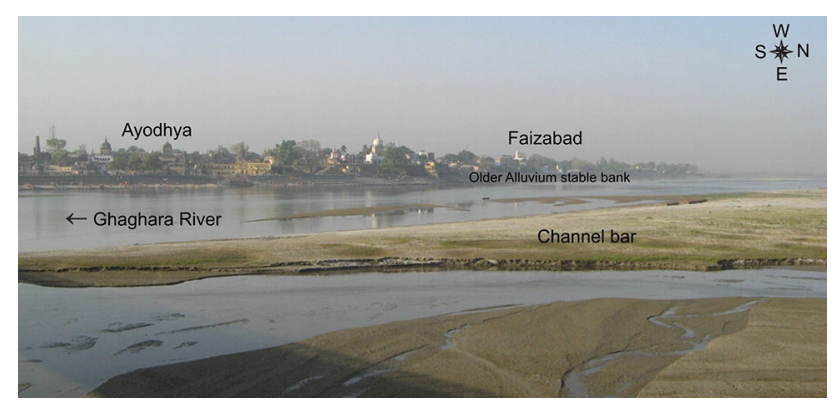

Fig. 5 Faizabad and Ayodhya towns are located on the Older Alluvium upland surfaces and their opposite side is Newer Alluvium surfaces

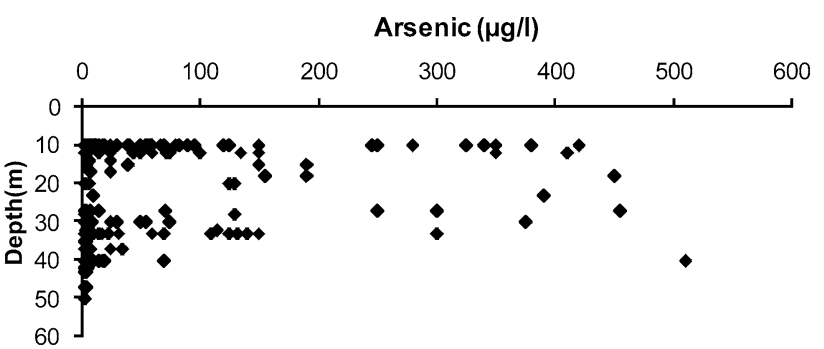

Fig. 6 Correlation between arsenic concentration and depth of tubewell in the Ghaghara Basin, Uttar Pradesh

The tubewells located in very shallow depth (10-20 m) in Faizabad, Gonda and Basti districts are 12, 31, and $62 \%$, respectively (Table 3 ). About 86,69 , and $35 \%$ of tubewells in Faizabad, Gonda, and Basti districts, respectively, are within the depth of 21-45 m. Maximum As concentration of $510 \mu \mathrm{g} / \mathrm{l}$ corresponds to a depth of $40 \mathrm{~m}$, as observed in Bhakir Mahangopur Village $\left(25^{\circ} 51.559^{\prime}\right.$ : $\left.82^{\circ} 07.669^{\prime}\right)$.

One $40 \mathrm{~m}$ hand-flapper borehole was done in As-affected Durgaganj Village $\left(26^{\circ} 49.128^{\prime}: 82^{\circ} 11.834^{\prime}\right)$. The subsurface sediments from ground level are as follows: $3 \mathrm{~m}$ top soil, 3-8 $\mathrm{m}$ grey clay mixed with fine sand, $8-9 \mathrm{~m}$ grey clayey shale, 9-20 m fine to medium grained greyish white sand mixed with clay, $20-21 \mathrm{~m}$ grey clayey shale, $21-30 \mathrm{~m}$ medium to coarse grained greyish white sand, $30-31 \mathrm{~m}$ grey clayey shale, $31-40 \mathrm{~m}$ coarse grained greyish white sand, and below $40 \mathrm{~m}$ yellowish brown clay with calcrete.

The sediments collected from the borehole at Durgaganj Village $\left(26^{\circ} 49.128^{\prime}: 82^{\circ} 11.834^{\prime}\right)$ are mainly Newer Alluvium. Arsenic and iron concentrations in clayey sand at Durgaganj Village are $6.19 \mathrm{mg} / \mathrm{kg}$ and $7.12 \mathrm{gm} / \mathrm{kg}$, respectively. Moreover, As concentrations in tubewells in and around of that borehole are 140, 125, and $410 \mu \mathrm{g} / \mathrm{l}$ (Fig. 2). It may be noted that the average As content in clayey sand is $12 \mathrm{mg} / \mathrm{kg}$ in Murshidabad district, and West Bengal (Acharyya et al. 2000). Arsenic and iron concentrations in clayey sand are $7.7 \mathrm{mg} / \mathrm{kg}$ and $4.26 \mathrm{gm} / \mathrm{kg}$, respectively, in Manikganj district, Bangladesh (Shamsudduha et al. 2008).

\section{Discussion}

\section{Relation of groundwater arsenic with Quaternary geomorphology}

The Quaternary sediments in the Indo-Ganga foredeep basin were deposited during Pleistocene period. Major deposit of sediments in the foreland basin has their source in the Himalayas under episodic tectonic activity and climate variability. However, minor inputs of sediments from 
Table 3 Depth of tubewell in As-contaminated areas in the Ghaghara Basin, Uttar Pradesh

\begin{tabular}{lllll}
\hline Study areas & $\begin{array}{l}\text { Depth } \\
10-20 \mathrm{~m} \\
(\%)\end{array}$ & $\begin{array}{l}\text { Depth } \\
21-45 \\
(\%)\end{array}$ & $\begin{array}{l}\text { mepth } \\
46-60 \\
(\%)\end{array}$ & $\begin{array}{l}\text { Max. } \\
\text { Depth } \\
(\mathrm{m})\end{array}$ \\
\hline $\begin{array}{l}\text { Faizabad district } \\
\quad(N=101)\end{array}$ & 12 & 86 & 2 & 60 \\
$\begin{array}{l}\text { Gonda district }(N=88) \\
\text { Basti district }(N=42)\end{array}$ & 31 & 69 & - & 43 \\
\hline
\end{tabular}

the Peninsular shield under cold, semiarid, and a warm humid palaeoclimatic conditions (Singh 2004). The Ganga Plain has developed a network of small drainages and entrenchment of the major rivers during $\sim 20$ to $13 \mathrm{ka} \mathrm{BP}$. The network became dense during 13-8 ka BP (early Holocene). During 8-6 ka BP small drainages changed to large lakes and extensive deposition of sediment took place in the upland interfluve surfaces. Most of the areas in the Ganga Plain are covered by $5-10 \mathrm{~m}$ thick muddy sediments, representing deposition during mid to late Holocene (Singh 2004).

Arsenic-contaminated tubewell in and around of Faizabad, Ayodhya, and Nawabganj towns are shown in Google satellite imagery. Geomorphologically, the Ghaghara Basin is subdivided into three zones viz. (1) Pleistocene Older Alluvium upland surfaces, i.e. Varanasi Older Alluvium, (2) older floodplains covered with Holocene Newer Alluvium sediments on top, and (3) Holocene Newer Alluvium entrenched channels and floodplains of the Ghaghara River (Fig. 7). Tubewells in Pleistocene Older Alluvium aquifers are As-safe in groundwater, whereas tubewells located in entrenched channels and flood plains of Holocene Newer Alluvium aquifers are Ascontaminated in groundwater. The latter occurs in proximity to meander or abandoned channels. It may be noted that high concentrations of groundwater As in alluvial aquifers in Bangladesh and West Bengal are reported in different parts of Bengal Delta. Arsenic contamination in groundwater in Bengal Delta is controlled by regional geologic-geomorphic units of Older Alluvium and Younger Alluvium sediments (Acharyya et al. 2000; von Brömssen et al. 2007; Shamsudduha et al. 2008).

The major parts of the Ghaghara Basin consist of interfluve upland surfaces of Older Alluvium. These Pleistocene Older Alluvium interfluve upland surfaces are characterized by yellow-brown coloured sediments with profuse calcareous and ferruginous concretions, and are either exposed or occur under shallow cover of Holocene sediments. In this study, Faizabad, Ayodhya, and Nawabganj towns in the Ghaghara Basin are located on the Pleistocene Older Alluvium upland surfaces, i.e. Varanasi Older Alluvium, and tubewells are As-safe in groundwater. Moreover, Holocene Newer Alluvium aquifers are characterized by grey to black coloured organic-rich argillaceous sediments, and tubewells in Holocene aquifers are As-contaminated in groundwater (Fig. 4). This may be comparable with the Bengal delta where high concentrations of groundwater As is found in Holocene aquifers, while Pleistocene aquifers have a low As level (Ravenscroft et al. 2009).

Arsenic contamination in groundwater in the Ghaghara Basin is shown in the schematic 3D diagram (Fig. 8). Tubewells located in the entrenched channels and floodplains of the Ghaghara River are mostly As-contaminated. Moreover, tubewells located in Pleistocene Older Alluvium aquifers with thin cover of Holocene sediments on top are As-safe in groundwater. Arsenic affected tubewells are also locally observed in older floodplains covered with Holocene Newer Alluvium sediments on top. This model regarding groundwater As can be applied in others fluvial-deltaic setting in South and South-East Asia as well. Groundwater As is mostly found in the delta plains, modern floodplains, marshes, and depressed lowlands areas in Red River Delta and Bengal Delta (Berg et al. 2001; Kinnibugh and Smedley 2001). High As areas are mainly characterized by low
Fig. 7 Google satellite imagery showing distribution of arseniccontaminated tubewells in entrenched channels and floodplains of the Ghaghara River

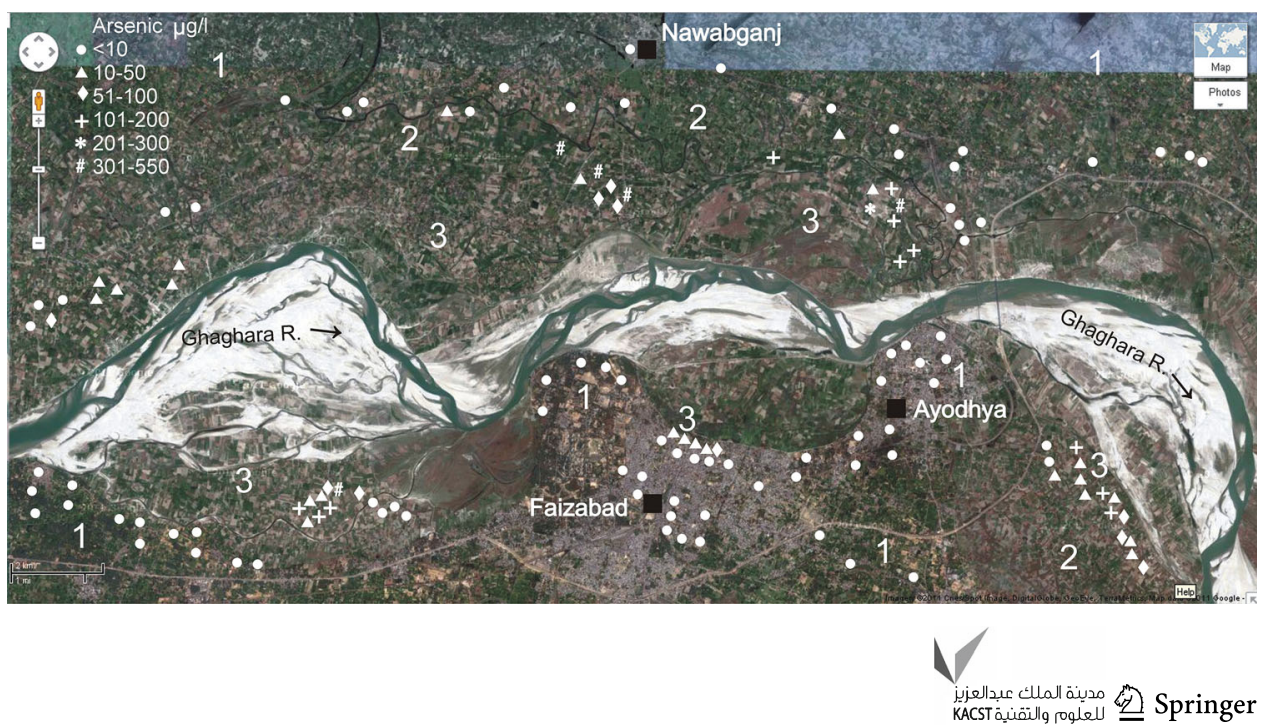




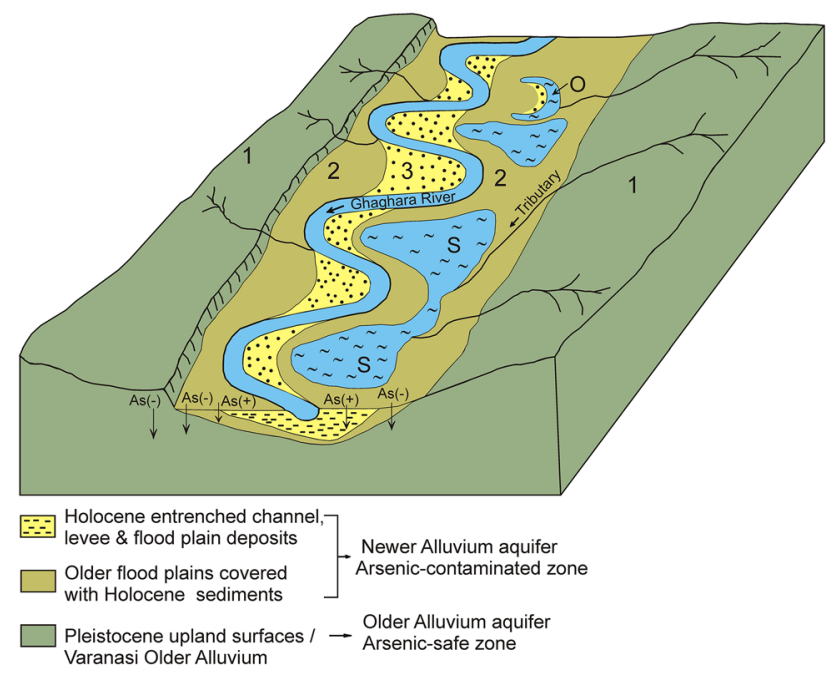

Fig. 8 Schematic 3D diagram showing groundwater arsenic status in Holocene and Pleistocene aquifers. O-Ox-bow lake, S-Back swamp, As (-) As-safe aquifers, As (+) As-contaminated aquifers

slopes in shallow aquifers where groundwater flow is mainly controlled by elevation and slope variations. Occurrences of high groundwater As are significantly linked with the Pleistocene and Holocene aquifers in the Red River Delta and Bengal Delta (Berg et al. 2001; Ravenscroft et al. 2009; Shamsudduha et al. 2008).

In the Ghaghara Basin, Pleistocene Older Alluvium yellow-brown coloured surfaces were subjected to erosion and oxidation, and were dissected by channels and floodplains and buried under younger Newer Alluvium sediments. These oxidizing Pleistocene upland surfaces were well flushed by groundwater flow due to high-hydraulic head and also devoid of organic matter. The environment of the oxidized Pleistocene Older Alluvium sediments is not favourable to release sorbed As to groundwater. However, deeper tubewells $(>50 \mathrm{~m})$ in Pleistocene Older Alluvium aquifers in the Ghaghara Basin would be a better option for As-safe groundwater.

\section{Source of arsenic in the Ghaghara Basin}

The Ghaghara Basin was formed due to accumulation of bulk sediments from the Himalayan hill range. There are several As bearing minerals deposits in the Himalayan hill range including hydrothermal pyrite-chalcopyritearsenopyrite-galena mineralization associated with quartz veins in Buniyal, Doda, Almora Garhwal, J and K Hills (Tewari and Gaur 1977). The Indus-Tsangpo suture in north India is marked by ophiolitic rocks, including olivine serpentinites. These ophiolites are composed of serpentinized peridotite, layered mafic to ultramafic rock, volcanic and oceanic sediments that contain high As (Guillot and Charlet 2007).
Terai belt of Nepal is As-contaminated, and the Terai sediments have come from the Himalayan hill range (Gurung et al. 2005). Most of the rivers in northern parts of the Gangetic Plain have originated from the Himalayan hill range. The Ghaghara River, the focus of present work, has also originated from the Himalayas and flows through the Terai belt of Nepal. Arsenic in suspended river sediments of the Ghaghara River is $7.11 \mathrm{mg} / \mathrm{kg}$ during monsoon period (Shah 2014).

\section{Conclusion}

Hand tubewell in Faizabad, Gonda, and Basti districts of Uttar Pradesh are prone to As contamination in groundwater. These tubewells are located in entrenched channels and floodplains of the Ghaghara River. It is observed that As-affected villages are preferentially located close to abandoned or present meander channels of the Ghaghara River. Most of the As-contaminated tubewells are in the depth range of $20-40 \mathrm{~m}$, which are located in Holocene Newer Alluvial aquifers. However, tubewells located on the Pleistocene Older Alluvium upland surfaces in Faizabad, Ayodhya, and Nawabganj towns are virtually As-safe in groundwater. The major parts of the Ghaghara Basin consist of upland oxidized Pleistocene yellow-brown coloured sediments. The environment of the Pleistocene Older Alluvium aquifers is not favourable to release As to groundwater, and aquifers are generally As-safe in groundwater. The Ghaghara River carries high content of As $(7.11 \mathrm{mg} / \mathrm{kg})$ in suspended river sediments. In Ascontaminated areas, deeper tubewells $(>50 \mathrm{~m})$ in Pleistocene Older Alluvium aquifers are considered as better option for As-safe drinking water.

Acknowledgement I thank IICB-Kolkata for As analysis. The author would like to thank local field assistants from Uttar Pradesh for helping to collect tubewells water and borehole sediments. The financial support of this study came from Department of Science and Technology Fast Track Young Scientist Scheme and Council of Scientific and Industrial Research Scientists' Pool Scheme, which is gratefully acknowledged.

Open Access This article is distributed under the terms of the Creative Commons Attribution 4.0 International License (http:// creativecommons.org/licenses/by/4.0/), which permits unrestricted use, distribution, and reproduction in any medium, provided you give appropriate credit to the original author(s) and the source, provide a link to the Creative Commons license, and indicate if changes were made.

\section{References}

Acharyya SK, Shah BA (2007) Groundwater arsenic contamination affecting different geologic domains in India-a review: influence of geological setting, fluvial geomorphology and Quaternary stratigraphy. J Environ Sci Health Part A 42:1795-1805 
Acharyya SK, Shah BA (2010) Groundwater arsenic pollution affecting deltaic West Bengal, India. Curr Sci 99:1787-1794

Acharyya SK, Lahiri S, Raymahashay BC, Bhowmik A (2000) Arsenic toxicity of groundwater of the Bengal Basin in India and Bangladesh: the role of Quaternary stratigraphy and Holocene sea level fluctuation. Environ Geol 39:1127-1137

Al-Mikhlafi AS (2010) Groundwater quality of Yemen volcanic terrain and their geological and geochemical controls. Arab J Geosci 3:193-205

Berg M, Tran HC, Nguyen TC, Schertenleib R, Giger W (2001) Arsenic contamination of groundwater and drinking water in Vietnam: a human health threat. Environ Sci Technol 35:2621-2626

Bhattacharjee S, Chakravarty S, Maity S, Dureja V, Gupta KK (2005) Metal contents in the groundwater of Sahebganj district, Jharkhand, India, with special reference to arsenic. Chemosphere 58:1203-1217

Biswas D, Banerjee M, Sen G, Das JK, Banerjee A, Sau TJ, Pandit S, Giri AK, Biswas T (2008) Mechanism of erythrocyte death in human population exposed to arsenic through drinking water. Toxicol Appl Pharma 230:57-66

Bureau of Indian Standards (2003) Indian standard: drinking water. Specification (first revision), Amendment No. 2, New Delhi

Chakraborty D, Mukherjee SC, Pati S, Sengupta MK, Rahman MM, Chowdhury UK, Lodh D, Chanda CR, Chakraborty AK (2003) Arsenic groundwater contamination in Middle Ganga Plain, Bihar, India: a future danger? Environ Health Perspect 111:1194-1200

Dhar RK, Biswas BK, Samanta G, Mandal BK, Chakraborty D, Roy S, Jafar A, Islam A, Ara G, Kabir S, Khan AW, Ahmed SA, Hadi SA (1997) Groundwater arsenic calamity in Bangladesh. Curr Sci 73:48-59

Dwivedi GN, Sharma SK, Prasad S, Rai RP (1997) Quaternary geology and geomorphology of a part of Ghaghara-RaptiGondak sub-basins of Indo-Gangetic Plain, Uttar Pradesh. J Geol Soc Ind 49:193-202

Guillot S, Charlet L (2007) Bengal arsenic, an archive of paleohydrology and Himalayan erosion. J Environ Sci Health Part A 42:1785-1794

Gurung JK, Ishiga H, Khadka MS (2005) Geological and geochemical examination of arsenic contamination in groundwater in the Holocene Terai Basin, Nepal. Environ Geol 49:98-113

Kashouty ME, Sayed EE, Kamel AA (2012) The hydrochemical characteristics and evolution of groundwater and surface water in the western part of the River Nile, El Minia district, Upper Egypt. Arab J Geosci 5:637-652

Kinnibugh DG, Smedley PL (2001) Arsenic contamination of groundwater in Bangladesh. British Geological Survey Report, WC/00/19, Dhaka
Kumar G, Khanna PC, Prasad S (1996) Sequence stratigraphy of the foredeep and evolution of the Indo-Gangetic Plain, Uttar Pradesh. Geol Surv Ind Spl Pub 21:173-207

Mondal BK, Suzuki KT (2002) Arsenic round the world: a review. Talanta 58:201-235

Nickson R, McArthur JM, Burgess W, Ahmed KM, Ravenscroft P, Rahman A (1998) Arsenic poisoning of Bangladesh groundwater. Nature 395:338

Nickson R, McArthur JM, Shrestha B, Kyaw-Myint TO, Lowry D (2005) Arsenic and other drinking water quality issues, Muzaffargarh District, Pakistan. Appl Geochem 20:55-68

Pascoe EH (1964) A Manual of the Geology of India and Burma. Geol Surv Ind Calcutta III:1980-2016

Pathak BD, Karanth KR, Kidwai AL, Rao AP, Bose BB (1978) Geology and groundwater resources in parts of Janupur, Azamgarh, Ballia, Allahabad, Sultanpur and Faizabad districts, Uttar Pradesh. Bull Geol Surv Ind Sr B 44:1-77

Ravenscroft P, Brammer H, Richards K (2009) Arsenic pollution: a global synthesis. Wiley Blackwell, Chichester

Shah BA (2008) Role of Quaternary stratigraphy on arsenic contaminated groundwater from parts of Middle Ganga Plain, UP-Bihar, India. Environ Geol 53:1553-1561

Shah BA (2014) Arsenic in groundwater, sediments, and suspended river sediments from the Middle Gangetic Basin, India: distribution, field relations, and geomorphological setting. Arab J Geosci 7:3525-3536

Shamsudduha M, Uddin A, Saunders JA, Lee MK (2008) Quaternary stratigraphy, sediment characteristics and geochemistry of arsenic-contaminated alluvial aquifers in the Ganges-Brahmaputra floodplain in central Bangladesh. J Conta Hydrology 99:112-136

Singh IB (2004) Late quaternary history of the Ganga Plain. J Geol Soc Ind 64:431-454

Srivastava NK (2009) Ground water brochure of Faizabad district, U.P (CGWB A.A.P. 2008-2009)

Tewari AP, Gaur RK (1977) Geological conditions of formation of Pyrite-Polymetallic deposits of the Himalaya and the Great Caucasus-a comparison. Him Geol 7:235-245

Tseng CH, Tai TY, Chong CK, Tseng CP, Lai MS, Lin BJ, Chiou HY, Hsueh M, Hsu H, Chen CJ (2000) Long term arsenic exposure and incidence of non-Insulin dependent diabetes mellitus: a cohort study in arseniasis-hyperendemic villages in Taiwan. Environ Health Persp 108:847-851

von Brömssen M, Jakariya M, Bhattacharya P, Ahmed KM, Hasan MA, Sracek O, Jonsson L, Lundell L, Jacks G (2007) Targeting low-arsenic aquifers in Matlab Upazila, Southeastern Bangladesh. Sci Total Environ 379:121-132

WHO (1993) Guideline for drinking water quality. Recommendations, 2nd edn. WHO, Geneva, p 1 